\title{
PHYTOCHEMICAL AND ANTIBACTERIAL ACTIVITY OF DIVERSE SOLVENT EXTRACT OF LEAF (Plumbagozeylanica).
}

\author{
D. Roselin Jenifer ${ }^{1, *}$ and B. R. Malathy ${ }^{2}$ \\ ${ }^{1}$ Department of Bioinformatics, Sathyabama Institute of science and technology, Chennai-119. \\ ${ }^{2}$ Department of Microbiology, Reader, Sathyabama Dental College and Hospital, Chennai-119. \\ *E-mail: jeni.christ20@gmail.com
}

\begin{abstract}
The present investigation is focused to assess the Phytochemical study and antibacterial activities of the leaf extract of Plumbagozeylanica. The leaf extracts were prepared by using various solvents with an increasing polarity such as hexane, chloroform, ethyl acetate and Methanol. The filtered extract was assessed for its activity against multifarious bacteria such as Staphylococcus aureus, Klebsiellapneumoniae, Bacillus cereus, Salmonella typhi and Pseudomonas aeruginosa by performing well diffusion method. Out of the four solvents trialled, ethyl acetate extract alone showed Zone of inhibition and confirmed significant activity against all the tested pathogens.
\end{abstract}

Keywords: P. Zeylanica, Phyto extract, Antibacterial activity, Well diffusion method.

(C) RASĀYAN. All rights reserved

\section{INTRODUCTION}

Indiscriminate use of antibiotics has led to an increased percentage of many defenses against a human harmful microorganism in recent times. Specific plants have restricted Heritance along with universal significance. Our country was blessed with a wealthy origin of medicinal plants. They form the main ingredients of the Indian system of medicine. Various forms of drug modified elements have been isolated from natural resources, especially plants. These kinds of the modern drug have been used to cure diseases in all places of the world. One such plant is Plumbago zeylanica belonging to family Plumbaginaceae. Its flowers are used as Digestant. ${ }^{1}$, leaves are used to treat scabies and dysentery.

The Root is pungent and has been used as Abortifacient, good appetizing agent, expectorant, tonic, useful in rheumatoid arthritis, detoxifier, skin infection, and disease of the spleen. ${ }^{2}$ Antiviral, Antifungal, Antibacterial,Antipneumococcal, Leishmaniases, Trypanophobia, and Anticarcinomic activity of different parts of P.zeylanica has been reported. ${ }^{3}$

Plumbago zeylanica comprises of important chemical composites for instance alkaloids, Napthaquinones, steroids, tannins, Glycosides, Triterpenoids, Flavonoids, Coumarins, Carbohydrates, Saponins, phenolic compounds, fats, fixed oil and proteins. ${ }^{4}$ A Polyphenolic compound from this plant possess Apoptotic, antibacterial, antioxidant and anticancer properties. ${ }^{5}$ Unfortunately, new lead molecules have not been synthesized so far. Hence, there is a need for in-depth research to know the mode of action, Bioactivity of various phytochemicals present and its medicinal values. The present study focused on Plumbago zeylanica leave extract using four different solvents based on polarity and its Phytochemical analysis and antibacterial activity.

\section{Solvent Extraction of Plant}

\section{EXPERIMENTAL}

The leaf of P. Zeylanica was purchased from the homoeopathic store. It was washed and shade dried for 15 days, then ground into powder. $100 \mathrm{~g}$ of powder was mixed with $200 \mathrm{ml}$ of solvents as per polarity (Hexane, Chloroform, Ethyl acetate and Methanol). The Blending of the mixture was done by keeping the flask on the orbital shaker at room temperature for 48 hours. It was filtered by Whatman No-1filterpaper and the filtrate was collected. Solvent from the filtrate was evaporated by rotary evaporator at low

Rasayan J. Chem., 12(2), 630-634(2019)

http://dx.doi.org/10.31788/RJC.2019.1225134

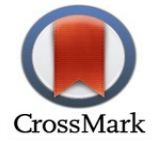




\section{RASĀYAN J. Chem.}

Vol. 12 | No. 2 |630 - 634| April - June | 2019

temperature under medium pressure condition. The dried crude extract was stored in the airtight container for further experiment and analysis.

\section{Phytochemical Screening}

The standard protocol ${ }^{6}$ was used to screen the presence of phytochemical constituents like carbohydrate, alkaloids, glycosides, saponins, phytosterols, the phenolic compound, flavonoids, amino acids, and tannins present in the plant extract. The observation of the phytochemical screening results was summarized in the Table-1.

\section{Test for Alkaloids}

$1 \mathrm{ml}$ of plant leaf extract diluted, mixed with $5 \mathrm{ml}$ Hydrochloric acid and was filtered. $1 \mathrm{ml}$ of Mayer's reagent added to the mixture to observe the change yellow precipitate formation.

\section{Test for Carbohydrates}

$1 \mathrm{ml}$ Plant leaf extract was added with $2 \mathrm{ml}$ of Fehling solution A and B and then boiled for 5 minutes. The red deposit showed the presence of reducing sugars.

\section{Test for Protein}

Two drops of Ninhydrin solution added with plant extract. This reaction produces a purple colour indicates the presence of amino acids.

\section{Test for Flavonoids}

$4 \mathrm{ml}$ of plant leaf extract was allowed to mix with $1.5 \mathrm{ml}$ of fifty per cent methanol solution. This mixture was heated along with metal magnesium then add 5-6 drops of concentrated $\mathrm{HCl}$ were added and orange colour was observed for Flavones and Red color for Flavonoids.

\section{Test for Saponins}

$2 \mathrm{ml}$ of leaf extract of the plant was added to $5 \mathrm{ml}$ of distilled water and kept on a shaker for 20 minutes Determination of the foam indicated presence of Saponine.

\section{Test for Steroid}

$0.5 \mathrm{ml}$ of plant leaf extract mixed well with acetic anhydrous. When this mixture cooled in an ice bath, add concentrated sulfuric acid. The Reddish brown colour identified the presence of steroid.

\section{Test for Terpenoids}

$5 \mathrm{ml}$ of plant leaf extract was treated in $2 \mathrm{ml}$ of chloroform and $3 \mathrm{ml}$ of concentrated $\mathrm{H} 2 \mathrm{so} 4$ added dropwise. The reddish-brown layer formed at the interface, thus shows the presence of Terpenoids.

\section{Test for Tannins}

$1 \mathrm{ml}$ of Plant leaf extract was added with $1 \mathrm{ml}$ ferric chloride. A greenish-brown precipitate showed the presence of tannins.

\section{Test for Phenol}

$1 \mathrm{ml}$ of Extract treated with $2 \mathrm{ml}$ of distilled water and add a few drops of $10 \%$ aqueous Ferric chloride. The presence of green or blue colour showed the existence of phenols.

\section{Antibacterial Effect of $P$. Zeylanica}

Antibacterial activity of leaf extracts was tested by the good diffusion method up against Staphylococcus aureus, Klebsiellapneumoniae, Bacillus cereus, Salmonella typhi, and Pseudomonas aeruginosa. Muller Hinton Agar was used for testing. Lawn culture of the bacteria was obtained on MHA using a sterile cotton swab. Wells was punctured using a cork borer. Leaf extract was added $(25 \mu \mathrm{l} / \mu \mathrm{g}, 50 \mu \mathrm{l} / \mu \mathrm{g}, 75$ 
RASĀYAN J. Chem.

Vol. 12 | No. 2 |630 - 634| April - June | 2019

$\mu \mathrm{l} / \mu \mathrm{g}$, and $100 \mu \mathrm{l} / \mu \mathrm{g}$ ) in the well along with the control. Plates were incubated at $37^{\circ} \mathrm{C}$ overnight. Plates were observed in the zone of inhibition around the well. The zones were measured on Millimetre scale. ${ }^{7}$

\section{Phytochemical constituents of the leaf extract of $P$. Zeylanica}

\section{RESULTS AND DISCUSSION}

The result of preliminary phytochemical screening carried out by solvent extraction using Hexane, chloroform, ethyl acetate and methanol leaf extracts of $p$. Zeylanica is given in the Table- 1 . Carbohydrates are in the Hexane extract. Flavonoids are present in the Hexane, ethyl acetate and methanol extract. Alkaloids, Terpenoidand phenolic compound are found in the chloroform and ethyl acetate extract. Saponins are in the methanol extract. At last tannins were found in the chloroform, ethyl acetate and methanol extract.

Polyphenols are a large and a contrasting form of compounds, many of which exist a naturally inaccurate range of herbs and food molecules. Flavonoids are one of the best polyphenols. Many of which have properties such as antioxidant, antimutagenic, Anticarcinogenic and anti-inflammatory effects. These kinds of polyphenols potentially inhibit the disease and control the strength of the genome. ${ }^{8}$

\section{Antibacterial Activity}

Extracts were tested for antibacterial activity by the good diffusion method. Among the four solvents used for extraction, only ethyl acetate extracts showed a zone of inhibition against bacteria tested (Staphylococcus aureus, Klebsiellapneumoniae, Bacillus cereus, Salmonella typhi, and Pseudomonas aeruginosa.). As the concentration of the extracts increases the zone of inhibition also increased. Zone sizes were shown in the Table-2 and Figs.-1 to 5.

Table-1: Preliminary Phytochemical Analysis of Plumbago zeylanica with Various Solvents

\begin{tabular}{|c|c|c|c|c|c|c|}
\hline S. No. & Phytoconstituents & Tests & Hexane & Chloroform & Ethyl Ecetate & Methanol \\
\hline 1. & Alkaloids & Mayer's test & - & + & + & - \\
\hline 2. & Carbohydrates & Molisch test & + & - & - & - \\
\hline 3. & Proteins & Ninhydrin test & _ & + & - & - \\
\hline 4. & Flavonoides & Alkaline test & + & _- & + & + \\
\hline 5. & Saponins & Froth forming test & - & - & - & + \\
\hline 6. & Steroid & Steroid test & - & + & _ & _ \\
\hline 7. & Terpinoids & Terpinoids test & _ & + & + & _ \\
\hline 8. & Tannins & $\mathrm{Fecl}_{3}$ test & 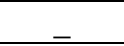 & + & + & + \\
\hline 9. & $\begin{array}{l}\text { Phenolic } \\
\text { compound }\end{array}$ & Lead acetate test & - & + & + & + \\
\hline
\end{tabular}

(-) Absent, (+) Present.

Table-2: Antibacterial Activity of Plumbago zeylanica against Salmonella typhi, Bacillus cereus, Pseudomonas aeruginosa, Staphylococcus aureus and Klebsiella pneumoniae.

\begin{tabular}{c|c|c|c|c|c|c|l}
\hline S. No. & $\begin{array}{c}\text { Plumbago } \\
\text { zeylanica } \\
\text { Organic Solvent } \\
\text { Extract }\end{array}$ & Microorganism & $25 \mu \mathrm{l} / \mu \mathrm{g}$ & $50 \mu \mathrm{l} / \mu \mathrm{g}$ & $75 \mu \mathrm{l} / \mathrm{g} /$ & $100 \mu \mathrm{l} / \mu \mathrm{g}$ & $\begin{array}{l}\text { Control } \\
\text { Ethyl } \\
\text { Acetate } \mu \mathrm{l} / \\
\mu \mathrm{g}\end{array}$ \\
\cline { 3 - 8 } & $\begin{array}{c}\text { Ethyl Acetate } \\
\text { Extract }\end{array}$ & $\begin{array}{c}\text { Salmonella } \\
\text { typhi } \\
\text { Inhibition } \\
\text { in } \mathrm{mm}\end{array}$ & $\begin{array}{c}10 \pm 0.1 \\
\text { Inhibition } \\
\text { in } \mathrm{mm}\end{array}$ & $\begin{array}{c}12 \pm 0.5 \\
\text { Inhibition } \\
\text { in } \mathrm{mm}\end{array}$ & $\begin{array}{c}\text { Zone of } \\
\text { Inhibition } \\
\text { in mm }\end{array}$ & $\begin{array}{l}\text { Zone of } \\
\text { Inhibition } \\
\text { in mm }\end{array}$ \\
\cline { 2 - 8 } & Bacillus cereus & $9 \pm 0.6$ & $10 \pm 0.5$ & $12 \pm 0.73$ & $\begin{array}{l}\text { No Zone of } \\
\text { Inhibition }\end{array}$ \\
\hline
\end{tabular}


RASĀYAN J. Chem.

Vol. 12 | No. 2 |630 - 634| April - June | 2019

\begin{tabular}{l|l|c|c|c|c|c|l}
\hline & $\begin{array}{c}\text { Pseudomonas } \\
\text { aeruginosa }\end{array}$ & $6 \pm 0.6$ & $7 \pm 0.56$ & $16 \pm 0.5$ & $17 \pm 0.5$ & $\begin{array}{l}\text { No Zone of } \\
\text { Inhibition }\end{array}$ \\
\cline { 2 - 7 } & $\begin{array}{c}\text { Staphylococcus } \\
\text { aureus }\end{array}$ & $8 \pm 0.5$ & $10 \pm 0.5$ & $14 \pm 0.53$ & $16 \pm 0.63$ & $\begin{array}{l}\text { No Zone of } \\
\text { Inhibition }\end{array}$ \\
\cline { 2 - 7 } & $\begin{array}{c}\text { Klebsiella } \\
\text { pneumoniae }\end{array}$ & $6 \pm 0.43$ & $9 \pm 0.66$ & $10 \pm 0.46$ & $15 \pm 0.76$ & $\begin{array}{l}\text { No Zone of } \\
\text { Inhibition }\end{array}$ \\
\hline
\end{tabular}

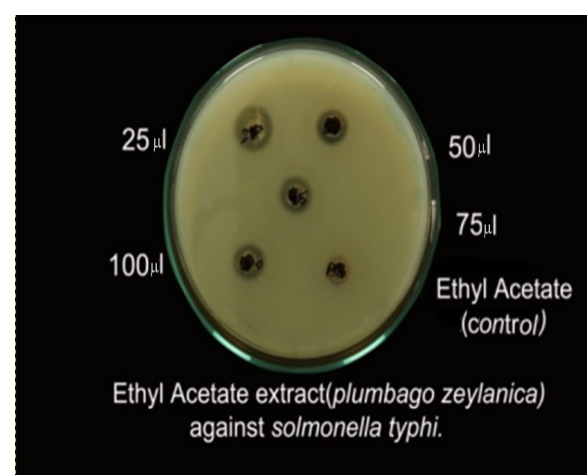

Fig.-1

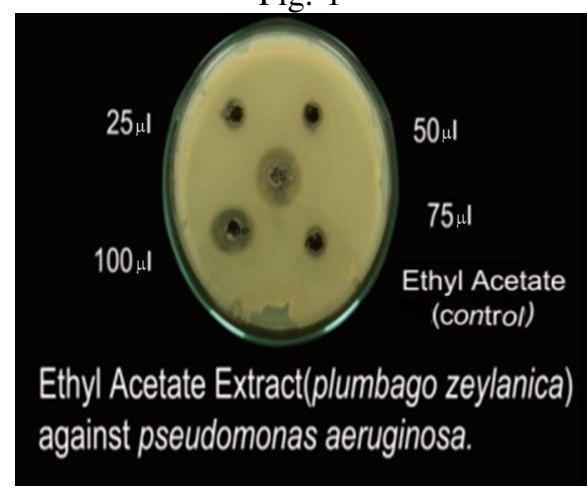

Fig.-3

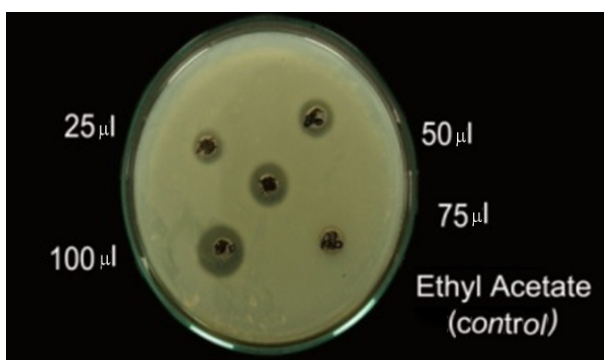

Ethyl Acetate extract(Plumbago zeylanica) against bacillus cereus.

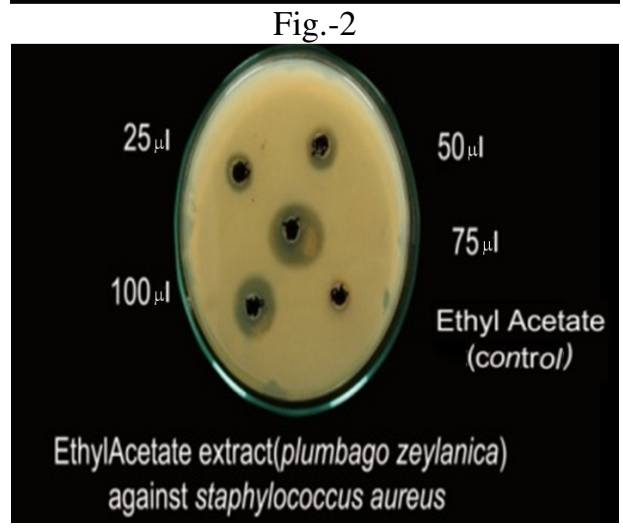

Fig.-4

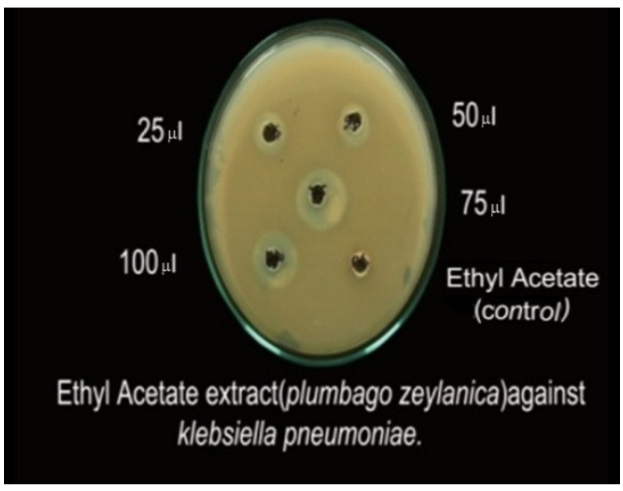

Fig.-5

\section{CONCLUSION}

Phytoconstituents analysis of leaf extract of $P$. zeylanicaconfirmed the presence of carbohydrates, alkaloids, glycosides, saponins, phytosterols, phenolic compounds, flavonoids, amino acids, and tannins. Among the four solvent extracts tested for antibacterial activity, Ethyl acetate showed the varying zone of 
inhibition depending on the concentration of the extract. Hence this study concludes that the ethyl acetate extract can be subjected to further study.

\section{ACKNOWLEDGEMENT}

My heartfelt thanks to my guide to giving suggestion and thanks to the Sathyabama Institute of Science and technology to provide the facility to fulfil this study.

\section{REFERENCES}

1. S.R.Paiva, S.S. Marques, M.R. Figueiredo, and M.A.C.Kaplan, Floresta e Ambiente, 10, 98(2003)

2. P. K. Mukherjee, Business Horizons, 38, 113(2002).

3. Nisha Sharma, Purshotam Kaushik, Journal of Pharmacognosy and Phytochemistry, 3(4), 117(2014).

4. Richa Tyagi, Ekta Menghani, International Journal of Pharma Sciences and Research, 5(3), 72(2015).

5. C. H. Beckman, Physiological and Molecular Plant Pathology, 57(3), 101(2000), DOI: 10.1006/pmpp.2000.0287.

6. A. Kolkata, Phytotherapy Research, 78, 126(1999).

7. I.C. Mohanty, K. Vishnu, Soni, and G.R. Sahu, Journal of Medicinal Plant Research, 8(18), 669(2014), DOI: 10.5897/JMPR11.1110.

8. L.R. Ferguson, Mutation Research, 475, 89(2001).

[RJC-5134/2018] 